\title{
SDGs Contribution to BRI Countries and Its Impact on China's Export-Based on Stochastic Frontier Approach
}

\author{
Wang Pei Zhi ${ }^{1, a}$, Hafiz Arslan Iqbal ${ }^{2, b}$ \\ ${ }^{1}$ Dean, Prof. \& Dr. of Faculty of International Economics and Trade, Shandong University of \\ Finance and Economics, 250014, Jinan, Shandong, P.R. China \\ ${ }^{2}$ Docotral Candidate of Shandong University of Finance and Economics, 250014, Jinan, \\ Shandong, China \\ asheila_guo1988@hotmail.com, barslaniqbalmughal@yahoo.com
}

Keywords: SDGs 8 and 9, BRI, LSDV estimator, stochastic frontier approach.

\begin{abstract}
This research paper identifies the impact on Chinese export by the contribution of Sustainable development goals (SDGs) to Belt and Road Initiative (BRI) countries. The study also deals with the assessment based on panel data by using a stochastic frontier approach to enhance the efficiency over the period of 2009-2018. The results indicate that SDGs' goals are significantly backing as helping hands to China's exports of goods and services in BRI countries. To best of our knowledge, there is no empirical study available to analyze the SDGs contribution in BRI countries by applying a stochastic frontier approach. This paper also draws attention that jointly works of two global initiatives could achieve aims in the forthcoming future. Furthermore, the outcomes of this research would be observed as tentative, and further work is more desirable.
\end{abstract}

\section{Introduction}

Since the world became a global village, the international trade and investment system kept facing systemic pressures. Meanwhile, in today's global economy, countries are signing a multilateral trade agreement and becoming more protectionist. The US-China trade war not only impacted both those giants but also shook the global and regional trade scenarios. As a top exporter in the World, China is now struggling to shift its US-dependency into other unexplored and potential markets in Asia, the Middle East, and Africa, and so on. In addition, the US also has a similar plan with a different cluster of regions. This is also due to the fact that both sides failed to strike a deal so far, and the increased tariffs are affecting their respective domestic markets. United Nations has launched millennium development goals (MDGs) in the year 2000 with the ambition to achieve all its objectives by 2015 that included eradicating poverty, hunger, employment, access to primary education, etc.

According to the annual report of MDGs 2015, poverty numbers have dropped from 1.9 billion people in 90 s to 836 million in $2015^{[1]}$. The assistance provided by developed countries rose from $\$ 81$ billion to $\$ 135$ billion between 2000 and 2014. In 2015, the United Nations presented blueprints of (SDGs) "Sustainable Development Goals" to continue the program for a better and more sustainable future called "Agenda 2030". The SDGs consist of 3 pillars: Economic Development, Human Development, and Environmental Protection. The main reason to transition MDGs into SDGs because there are still 800 people living with less than $\$ 1.25$ earning per day ${ }^{[2]}$. World Bank report states that BRI-investment in infrastructure development also prospered favorable outcomes in the reduction of shipping time, trade cost, unemployment, poverty, and transfer technology ${ }^{[3]}$. According to Stecher, the material for the building have a significant effect directly and indirectly in order to achieve SDGs. These goals are included SDG 3,6,7,8,9,11 and $12^{[4]}$. multiple researchers explained the significant of SDG 9 that, resilient infrastructure is connected from the usage of green, durable, alternative, environmentally friendly, energy-efficient and responsibly sourced material of building to construct and facilitate the businesses ${ }^{[5]}{ }^{[6]}$. Recently Secretary-General of UNs 
visited Beijing and openly supported to aligning China's BRI and SDGs ${ }^{[7]}$. Goal 8 deals with "Promote sustained, inclusive and sustainable economic growth, full and productive employment, and decent work for all'. According to the New SDG report 2019, as a proxy of a standard of living, real GDP per capita has boosted worldwide by $1.95 \%$ as compared to 1.3 from 2017 and 2016, respectively ${ }^{[8]}$. Moreover, in the least developed countries (LDCs), real GDP per capita has accelerated from an average rate annually 5.8 in 2000-2004 to 7.1 over 2005-2009, before slowing to 4.8 by 2010-2017 and It is expected to hike to 5.7 till 2020 . However, this is yet to be done and not as much as the UNs set target. Thus, more precise policies are needed to take towards the next sustainable growth level. Due to lack of financial services, small-scale industries that are considered to be the backbone of industrial development in developing countries, because of less foreign investment and local resources, most of the industries are facing a challenge to access to loans and credit for daily business activities. Goal 9 covers "Build resilient infrastructure promote inclusive and sustainable industrialization and foster innovation. This goal is the main key to spread new technology by facilitating international trade and permit the usage of resource efficiency. According to the SDG report 2019, total official flows for infrastructure in developing countries have gone \$59 billion by 2017 as this is a 32\% increment in the real term. The overall share in manufacturing value added (MVA) in GDP increased a bit 15.9 to 16.5 percent over 2008$2018{ }^{[9]}$. On the other hand, China's direct investment in BRI countries has grown by 5.2\% annually from the year 2013 to 2018 and received a $\$ 40$ billion investment from BRI countries ${ }^{[10]}$. Recently, China has established the New China Bank to finance the BRI project ${ }^{[11]}$. Now the new concern is not about the doubt of BRI. However, policymakers are debating how much BRI helps to achieve the 2030 Agenda to eradicate poverty, provide better access to health care, ensure food security, environmental protection, and create profitable corporations among nations through trade liberalization ${ }^{[12]}$. China is a global phenomenon, and since 1978, the Chinese have been working hard to open up the economy to the world. China was able to achieve double-digit economic growth for a sustainable period of time. The economy has been changed over recent decades; meanwhile, China intends to pour an extreme investment of around US\$1.5 trillion in BRI countries until 2025. It would be a record surpass FDI ever by China or any country. Even the US in the past invested far less and was a rival for global dominance ${ }^{[13]}$. While BRI has emerged with a wide economic policy having compelling aspects ${ }^{[14]}$. The paper also catches attention to define the importance of the Belt and Road Initiative (BRI) in facilitating the enforcement of the Agenda 2030 for the (SD) Sustainable Development and vice-versa. Sustainable Development Growth has 17 Goals, 169 targets, 243 indicators, and all are theoretically, methodologically reliable, well designed, and tested to function reliably ${ }^{[15]}$. A growing body of empirical research has worked on Belt and Road initiatives, and China's long term vision in the Middle East ${ }^{[16]}$. Very little research has been conducted on the empirical results of SDGs in BRI countries. Generally, different authors have reported many research studies on new directions and abruptly state their problems. So far, much theoretical work has been published on the infrastructure, regions, and districts wise of BRI participants. Empirical studies have indicated various characteristics of infrastructure development like the Silk Road Economy Belt, at land or state. The main objective of this study to measure the impact on Chinese export by the contribution of Sustainable development goals in BRI countries. Particularly, by using the indicators from the SDGs database, this study has chosen the most relevant variables from goals 8 and 9 and its contributions in a group of Belt and Road initiative countries to assess the Chinese export.

\section{Empirical review}

Research related to the practical review of infrastructure investment and trade performance is 
assorted; however, it concluded different results on account of direction and intensity of effects are substantial. Mr. Hong concluded that BRI accelerates the achievement of SDGs and the implementation of the 2030 Agenda ${ }^{[17]}$. Similarly, Dong indicated that China needs to promote green construction under BRI and look at more association mutually with 2030 SDGs ${ }^{[18]}$. An author empirically concluded with the Grange Causality model that inward FDI promotes the exports in China and also leaves the impact on labor-intensive industries domestically ${ }^{[19]}$. In the same way, Weishi examined by using the Fixed Effect Model that a $1 \%$ increase in FDI as a result of rising in $8.8 \%$ of China's exports ${ }^{[20]}$. Frey explained that SDG 8 "Promote economic growth, full employment, and decent work for all" and consummated the uncertainty in SDG 8 not only gives you liberty for accountability on human rights and monitoring but also promotes the legitimacy for the business approach [21]. Likewise, Rai theoretically quantified that gender and labor rights highlight the SDG 8 as it sustained growth economically and decent work ${ }^{[22]}$. Horn concluded that SDGs in middle-income economies could not sufficient conditions for development as that also needs to be embraced political structure, which considers a significant ingredient for growth ${ }^{[23]}$. Mukwaya analyzed the results on the "Global Trade Analysis Project" (GTAP) and concluded the import and export margin reduced $10 \%$ due to an increase in the growth rate of East Africa from 0.4 to $1.2 \%{ }^{[24]}$. Gong analytically measured the ICT sector in China, which has concerned with producing investment in both the public and private sectors but also a significant interest in BRI member countries ${ }^{[25]}$. An author analyzed economic belt and maritime Road are on back to sign multilateral trade treaties and welfare relations among China and linked BRI members ${ }^{[26]}$. Honghui analytically explained that more than 40 countries had been ratified an agreement with China, and over 100 countries are being part of BRI to be meant as BRI has a cogent impact on executing the sustainable development goals ${ }^{[27]}$.

\section{Source of data and estimation}

The main aim of the study was to evaluate the impact on Chinese export by the contribution of SDGs, particularly goals 8 and 9 in BRI countries. This study includes 27 countries under the Belt and Road Initiative of China by obtaining the yearly data from 2009-2018. The data has 1080 observations by splitting into quarters via E-views in order to increase credibility and produce more accurate results. For the data, Initially, LSDV Estimator has been adopted to evaluate the relationship of variables. The previous empirical study used the GTAP and GGE model and GTAP 10 database to check the BRI trade in Eastern Africa ${ }^{[28]}$. The reason for LSDV is because it shows a better relationship and changes in variables as compared to the random effect. It is a more appropriate extended estimator of a fixed effect that generates auto-dummies for all the countries since every country has different characteristics and patterns. Therefore, it is considered the most robust approach to tackle the variation in explanatory variables. The random effect has also been checked to evaluate the relationship for our predictor. Stochastic frontier approach (STA) has testified further as it is a better approach to measure time-invariant, which considered constant in LSDV fixed and random effect. STM is more suitable to control endogeneity and increase efficiencies to estimate the panel data. To best of our knowledge, no empirical study has been conducted to determine the Chinese export's impact with the contemplation of SDGs in BRI by using a stochastic frontier approach. Heckman selection model, the stochastic frontier approach has been adopted to grab the unbiased results. Likewise, various indicators from both sides of demand and supply factors, social, geographical, and institutional characters have been quantifying in order to measure the export performance. A Firm-level study revealed the insights to know how export works. Numerous authors have broadened the understanding of time and indicators that are important for a firm to decide for international export [29] [30]. All the 
variables are described in table 1 below.

Table 1: Description and Measurement of Variables

\begin{tabular}{|c|c|c|}
\hline Variables & Label & Description \\
\hline Exports of goods and services & $(\mathrm{EXP})$ & Export of goods and services as a \% of GDP. \\
\hline Aid for trade commitment & (AFTCM) & $\begin{array}{l}\text { Total official flows (commitments) for Aid for Trade, by } \\
\text { recipient countries (US dollars) }\end{array}$ \\
\hline Aid for trade disbursement & (AFTDM) & $\begin{array}{l}\text { Total official flows (disbursement) for Aid for Trade, by } \\
\text { donor countries (US dollars) }\end{array}$ \\
\hline Manufacturing VA per capita & $(\mathrm{MF})$ & Manufacturing value added per capita (US dollars) \\
\hline Aid for infrastructure & $(\mathrm{AFI})$ & $\begin{array}{l}\text { Total official flows for infrastructure, by recipient } \\
\text { countries (US dollars) }\end{array}$ \\
\hline Number of Bank branches & $(\mathrm{BRCH})$ & Number of commercial bank branches per 100,000 adults \\
\hline Number of ATMs & (ATM) & Number of automated teller machines per 100,000 adults \\
\hline
\end{tabular}

Source: The Authors

\section{Estimation results}

The Step-wise econometric estimations are explained from descriptive statistical analysis. The observation range for all variables is 1080. The Standard deviation value of some variables like ATM and $\mathrm{BRCH}$ indicates wider dispersion and the mean values of the variables; EXP, AFTCM, AFTDM, AFI, and MF exhibit lower dispersion since standard deviation are diverse from the mean value. The correlation among the variables has represents the strength of the relationship between the variables. It shows no issue of multicollinearity in our model. The variables epitomize weak correlation as well as the strong bond among most, which refers to be adequate conjunctions. Table 2 is the comparison of the Random effect, LSDV estimator, and stochastic frontier approach analysis. We have run a diagnostic test to check whether the LSDV estimator or random effect provides more accurate results. Therefore, based on the p-value showed up in the Hausman test, we have selected the LSDV estimator is robust and appropriate for our study. Further, the stochastic frontier model has been applied in order to enhance the efficiency of the LSDV estimator. The stochastic frontier technique was developed by Aigner, Lovell, and Schmidt in 1977. Since the conception of the idea, this approach has been widely applied to analyze the firm's performance and to increase the efficiencies of trade. Typically, the stochastic frontier model (SFM) postulates a production possibility frontiers representing the optimal level of production obtained from fixed available input. The efficient firms operate on production possibility boundaries, whereas technically inefficient firms operate inside the given frontier level, and also, it is representing production loss equal to the difference between actual and potential output. Hence, it implies that the latter can further expand its output from the given level of inputs. Thus stating in the context, the firm operating below the optimal level of production commits technical inefficiency. Similarly, SFM is a better methodology in dealing with the trade below than the optimal level. In this methodology, SFM is an appropriate methodology if inefficiency is proved as significant. Since we are working with panel data models, there a significant chance of endogeneity and inefficiencies in data to occur. The equation is below,

$$
\ln \operatorname{Exp}_{i t}=\beta_{0}+\beta_{1} A F T+\beta_{2} M F_{i t}+\beta_{3} A F I+\beta_{4} A F C_{i t}+\mu
$$

In the equation, $i$ represents a country, $t$ time, and $\mu$ is an error term. AFT has two indicators, Total official flows (commitments) for Aid for Trade, by recipient countries. (AFTCM) Total official flows (disbursement) for Aid for Trade, by donor countries. (AFTDM). (MF) Manufacturing value added per capita (constant 2010 United States dollars). (AFI) Total official flows for infrastructure, by recipient countries (millions of constant 2016 United States dollars). Access to financial services (AFC) consists of 2 variables, Number of 
automated teller machines (ATMs) per 100,000 adults (ATM), Number of commercial bank branches per 100,000 adults $(\mathrm{BRCH})$. To balance the unit of all variables, a log has been taken for variables that had values in dollars.

Table 2: Data Analysis

\begin{tabular}{|c|c|c|c|}
\hline Variable & Random & LSDV Fixed & Stochastic Frontier \\
\hline AFTCM & $.1741113 * * *$ & $.1783677 * * *$ & $.1475821 * * *$ \\
\hline AFTDM & $.1059713^{*}$ & $.0949573 *$ & $.088834 *$ \\
\hline $\mathrm{MF}$ & $1.446163 * * *$ & $1.435605 * * *$ & $1.41487 * * *$ \\
\hline AFI & $.1514199 * * *$ & $.1456651 * * *$ & $.1314948 * * *$ \\
\hline $\mathrm{BRCH}$ & $.0331864 * *$ & $.0535861 * * *$ & $.026465 * *$ \\
\hline ATM & $-.0076975 * *$ & $-.0105579 * * *$ & $-.0185436 * * *$ \\
\hline cons & $12.89061 * * *$ & $10.57726^{* * *}$ & $16.21908 * * *$ \\
\hline
\end{tabular}

In table 2, Aid for Trade Commitments (AFTCM) has found to be positively significant in Random Effect, Fixed Effect, and STA. As the magnitude of the coefficient is concerned, the variable has shown a greater impact on exports of china in LSDV as compared to the Stochastic Frontier Model. LSDV has its own specification, but since it is not appropriate to handle the endogeneity problem, we moved to STA. Similarly, AFTDM indicates positively significant in all models, while it was the lowest value in FTA. Manufactured value added (MF) can be seen as a significant and positive impact on China's exports in all the models, with a larger impact in LSDV, while STA has shown the least impact on China's exports. Total official flows for infrastructure (AFI) to recipient BRI countries has a significant positive impact on exports of China, with a larger impact shown in random and least in FTA. Likewise, Bank Branches located in BRI countries have a positive and significant impact on Chinese export while coefficients were least in STA and hike in random. ATMs installed in BRI participating countries have strongly significant in our models but have a negative impact on Chinese export with more in magnitude. Overall the output is strongly significant for all models, but when it comes to acceptance of results, the random effect does not handle every country specifically while LSDV generates auto-dummies for 27 BRI countries and dealt on the bases of countries' characteristics and pattern. Diagnostics test also recommended that the LSDV estimator has more profound results as compare to random effect, but our main test is a stochastic frontier approach that is considered best to handle time-invariant, endogeneity problems and increase the efficiency.

\section{Conclusion}

This paper attempted to determine the impact on Chinese export by the UN's contribution to sustainable development goals in the Chinese Belt and Road initiative group of countries. The finding showed a strongly significant and positive impact of SDGs, which means SDGs comes up as a gauge to achieve BRI's ambitions. According to the annual report of MDGs 2015, "Total official flows of infrastructure by recipient countries" have increased from $65 \%$ to $79 \%$ from 2000-2015. Our finding reveals that "Total official flows for infrastructure by recipient countries" showed reliable investment for BRI countries and bringing the benefits to trade with China. Even we have seen infrastructure has been improving in BRI countries as compared to the last decade. According to the SDGs report 2017, total official flows for economic infrastructure in developing countries have reached $\$ 59$ billion in 2017 as compared to $32.5 \%$ in 2013. Similarly, our finding depicts that aid for trade by recipient countries helping BRI countries to sign FTA agreement and regional multilateral agreements with China. Moreover, aid for trade commitment and disbursement shows significantly positive results, but the coefficient value of "aid for trade disbursement" is a bit less. From 
the existing literature, all commitments had met within two years, with the overwhelming majority met immediately. It seems that the commitments are never to be fully met in some sectors. However, aid tends to be disbursed in full or almost immediately. There are also substantial differences between countries. As in the least develop and underdevelop countries, the ratio of disbursement is less in terms of investment for the industrial sector. Moreover, it is already understood that manufacturing is an essential key to enhance the export, and our results also matched with this. In the case of access to financial services, ATM presented significant but negatively related to China's export while our study suggested that BRI countries are moving towards telecom transactions that will help to push capital circulation and strengthen the financial system of a country. It will also bring more opportunities for people to invest in domestic businesses when they have more access to capital. Ultimately, the increment of local industrial productivity will lead to less import from China. The finding also shows that bank branches are the only source to involve businesses in international trade. The overall result of the study revealed that SDGs are contributing well to BRI countries and they end up in China's exports. Since the United Nations is pushing its member countries to accomplish SDGs, it has driven a robust and sustainable move throughout the globe. Meanwhile, China has successfully rectified more than 100 countries, which could be a parallel struggle to moving forwards towards achieving Agenda 2030.

\section{References}

[1] The institutional document (2015). The Millennium Development Goals annual report. United Nations New York.

[2] Melitz, M. J. (2003). The impact of trade on intra- industry reallocations and aggregate industry productivity. Econometrica, 71(6), 1695-1725. https://doi.org/10.1111/14680262.00467

[3] World Bank Post, (2018). Belt and Road Initiative, weblog [Online] Available from:(https://www.worldbank.org/en/topic/regional-integration/brief/belt-and-road initiative)

[4] Stecher, A. Q., Collin, C., \& Linnet, A. (2018). Construction Product Declarations and Sustainable Development Goals for Small and Medium Construction Enterprises. Procedia CIRP, 69(May),54-58.https://doi.org/10.1016/j.procir.2017.12.011

[5] Hossain, K. M. A. (2015). Sustainable Infrastructure Development Strategies through Technological Innovation of Smart Materials. Journal of Emerging Trends in Engineering and Applied Sciences (JETEAS), 6(7), 180-187.

[6] Pour-Ghaz, M. (2013). Sustainable infrastructure materials: Challenges and opportunities. International Journal of Applied Ceramic Technology, 10(4), 584-592. https://doi.org/10.1111/ijac.12083

[7] Secretory General of UNs (2019). https://www.un.org/press/en/2019/sgsm19556.d oc.htm

[8] The Sustainable development goals report (2019). https://unstats.un.org/sdgs/report/2019/The-Sustainable-Development-Goals-Report2019.pdf

[9] Pradhan, P. (2019). Antagonists to meeting the 2030 Agenda. Nature Sustainability, 2(3), 171-172. 
[10]Xiaojin, Nan, (2019). Investment Spurs BRI countries' growth. China Daily Post. Available from (https://www.chinadaily.com.cn/a/201904/23/WS 5cbe4b9aa3104842260b7a07.html)

[11]Hideo Ohashi (2018) The Belt and Road Initiative (BRI) in the context of China's opening-up policy, Journal of Contemporary East Asia Studies, 7:2, 85-103, DOI: $10.1080 / 2476128.2018 .1564615$

[12]Li, K. X., Jin, M., Qi, G., Shi, W., \& Ng, A. K. (2018). Logistics as a driving force for development under the belt and road initiative- the Chinese model for developing countries. Transport Reviews, 38(4), 457-478.

[13] Tracy, E. F., Shvarts, E., Simonov, E., \& Babenko, M. (2017). China's New Eurasian ambitions: the environmental risks of the Silk Road Economic Belt. Eurasian Geography and Economics, 58(1), 56-88.

[14] Shahriar, S., Qian, L., Saqib Irshad, M., Kea, S., Muhammad Abdullahi, N., \& Sarkar, A. (2018). Institutions of the Belt \& Road Initiative: A Systematic Literature Review. JL Poly \& Globalization, 77, 1.

[15] Janoušková, S., Hák, T., \& Moldan, B. (2018). Global SDGs Assessments: Helping or Confusing Indicators?. Sustainability, 10(5), 1540.

[16]Lin, C. (2017). The Belt and Road and China's Long-term Visions in the Middle East. Retrieved November 5, 2017.

[17]Hong P. (2017). Strengthening national policy capacity for jointly building the Belt and Road towards the Sustainable Development Goals, "capacity development project financed by UN Peace and Development".

[18] Dong L, Yang X, Li H, (2018). The Belt and Road Initiative and the 2030 Agenda for Sustainable Development: seeking linkages for global environmental governance. Chinese Journal of Population Resources and Environment. DOI: 10.1080/10042857.2018.1487745.

[19]Routley, V., Ozanne-Smith, J., Li, D., Yu, M., Wang, J., Zhang, J. \& Qin, Y. (2008). Is China belting up or down? Seat belt wearing trends in Nanjing and Zhoushan. Accident Analysis \& Prevention, 40(6), 1850-1858.

[20] Gu, W., Awokuse, T. O., \& Yuan, Y. (2008). The contribution of foreign direct investment to China's export performance: Evidence from disaggregated sectors (No. 382-2016-22568).

[21]Frey, D. F. (2017). Economic growth, full employment, and decent work: The means and ends in SDG 8. The International Journal of Human Rights, 21(8), 1164-1184

[22] Rai, Shirin M. \& Brown, Benjamin D. \& Ruwanpura, Kanchana N., 2019. "SDG 8: Decent work and economic growth - A gendered analysis," World Development, Elsevier, vol. 113(C), pages 368-380.

[23] Horn, P., \& Grugel, J. (2018). The SDGs in middle- income countries: Setting or serving domestic development agendas? Evidence from Ecuador. World Development, 109, 7384.

[24] Mukwaya, R., \& Mold, A. (2018). Modeling the economic impact of the China Belt and Road Initiative on countries in Eastern Africa. 
[25] Renwick, N., Gu, J., \& Gong, S. (2018). The impact of BRI investment in infrastructure on achieving the Sustainable Development Goals.

[26]Dong, L., Yang, X., \& Li, H. (2018). The Belt and Road Initiative and the 2030 Agenda for Sustainable Development: seeking linkages for global environmental governance. Chinese Journal of Population Resources and Environment, 16(3), 203-210.

[27]Honghui C. Ting G, (2017). Building a shared vision for the belt and road initiative and sustainable development goals. UNDP CCIEE, China Centre for International Economic Exchanges.

[28] Mukwaya, R., \& Mold, A. (2018). Modeling the economic impact of the China Belt and Road Initiative on countries in Eastern Africa.

[29] Melitz, M. J. (2003). The impact of trade on intra- industry reallocations and aggregate industry productivity. Econometrica, 71(6), 1695-1725.

[30]Roberts, M. J., \& Tybout, J. R. (1997). The Decision to Export in Colombia: An Empirical Model of Entry with Sunk Costs. American Economic Review, 87(4), 545-564. 